and may well have repercussions farther afield. That is one reason why the reviewer thinks this Report might have been a little stronger.

Note.-The Report of the Game Policy Committee is obtainable from the Government Printer, Nairobi. Price 5s.

\title{
THE SURVIVAL SERVICE COMMISSION
}

\section{[By C. L. Boyle, Chairman}

In August, 1949, the International Union for the Protection of Nature held a conference at Lake Success, U.S.A., under the good offices of UNESCO. The conference was attended by representatives from thirty-two countries and from all the continents. The first subject to be studied was education in nature protection. The second was ecology and this was divided into sections of which Section $f$, under the chairmanship of Mr. Harold J. Coolidge, was devoted to " Emergency Action for preserving vanishing species of flora and fauna". The deliberations of this section resulted in Resolution No. 15 of the main conference which reads : "That the International Union for the Protection of Nature should establish a 'Survival Service' for the assembling, evaluation, and dissemination of information on and the study of, all species of fauna and flora that appear to be threatened with extinction, in order to assist governments and appropriate agencies in assuring their survival."

Then follows a list of thirteen birds and fourteen mammals.

Thus was born the Survival Service Commission of what is now the International Union for Conservation of Nature and Natural Resources. It is but the latest of a series of international efforts for the preservation of wild life. Among others are the International Treaty for the Protection of Pacific Fur Seals, 1911, the Anglo-American Convention for the Protection of Migratory Birds, 1916, the London African Convention, 1933, the International Whaling Convention, 1937, the Convention on Nature Protection and Wild Life Preservation in the Western Hemisphere, 1942. Treaties and conventions such as these do not arise spontaneously; they follow years of hard work, first by national societies and then by other bodies whose task it is to translate the work into the international sphere. There are committees for international wild life protection in Great Britain, the Netherlands and the United States of America. There is the International Committee for Bird Preservation. Finally there is the Union itself. 
In many countries, certainly in Great Britain, it is still extremely hard to get support for this international work. The interest in preservation is present, but its practical application in the form of donations or of membership of a society devoted to international wild life protection, seems to be directly proportional to the amount of work which the body can do, in full view, so to speak, of its supporters. This is understandable but most regrettable, for wild life knows no national boundaries. Successful work to protect birds in their northerly breeding places, for instance, may be nullified by unrestricted slaughter during migration or in winter habitats. A real determination in advanced countries, demonstrated by the support of tens of thousands of people to international conservation, would save the wild fauna of the world from the extermination now threatening it.

The work of the Survival Service since its foundation may be summarized as-action based on sound information. At Lake Success the Service prepared a list of thirteen birds, discussed later, and fourteen mammals, on whose behalf immediate and vigorous action was needed. A few changes have since been made and the mammals list now reads : Tasmanian wolf; Asiatic lion; Indian, Javan and Sumatran rhinoceroses; Tamarao (a dwarf buffalo from Mindoro, Philippines); Arabian oryx ; wisent (European bison); Cretan wild goat; Angolan giraffe; giant sable antelope; Nubian and Persian wild asses; chinchilla (all species); Cuban and Hispaniolan solenodons (two large insectivores); black-footed ferret (U.S.A.); Key deer of Florida; Caribbean and Hawaiian monk seals; Przewalski's horse; Bactrian camel; Suleman markhor; Bawean deer ; Guadalupe fur seal.

During the course of its work the Survival Service Commission has either been responsible for, or taken some part in the following activities :- -

(1) Repeated representations to the Indonesian Government on behalf of the Javan rhinoceros, now surviving only in the Udjung Kulon reserve on the west tip of Java. This rhinoceros was protected before the war by the Dutch and during the war by the Japanese. In the hiatus immediately after the war, Chinese poachers tried to kill the rhinoceroses, but it seems that, by killing a poacher in the reserve, a tiger came to the aid of the conservation. Then a rumour was spread that all other poachers would suffer a similar fate and the Javan rhinoceros was saved. According to our latest information, there are now between thirty and forty Javan rhinoceroses in Udjung Kulon cared for 
by a considerable staff who have two patrol boats at their disposal.

(2) In 1952 Mr. Hugh Farmar went to Crete to investigate the status of the Cretan wild goat and to set in motion measures for the animals' preservation.

Encouraging reports about this animal were received in 1958 during the Athens meeting of the Survival Service.

(3) During $1955 \mathrm{Mr}$. Lee Talbot, a Californian ecologist, visited thirty countries in Asia and N.E. Africa and made recommendations for conservation, some of which have been implemented. On his way back to America Mr. Talbot gave a most interesting lecture on his mission to the Fauna Preservation Society. Immediately afterwards he accompanied Mr. R. M. Arundel to the Serengeti National Park, Tanganyika, and made a short ecological report on the area. This report was very useful to the Fauna Preservation Society in their investigations of the Serengeti problem, which eventually led up to Professor Pearsall's ecological survey.

(4) In 1957 Mr. J. J. Petter, of the French National Museum of Natural History, investigated the status of lemurs in Madagascar. As a result of this and following a recommendation by the Union, a reserve for lemurs was made in a strip of coastal forest, perhaps the last remaining home of the aye-aye.

(5) In $1958 \mathrm{Mr}$. Oliver Milton embarked on an expedition to Burma. This mission is intended to last one or two years and to provide information and make recommendations for conservation in that country. In Burma the Survival Service is especially concerned with the preservation of the Sumatran rhinoceros.

(6) Following disturbing reports about the Great Indian rhinoceros in Nepal (published in Oryx IV, 6) the Service has now asked Mr. E. P. Gee to go to Nepal to investigate the status of the rhinoceros and to make recommendations for its status preservation.

Many individuals, societies and other bodies have worked together to make these missions possible. Very special recognition must be given to the American Committee for Internationa] Wild Life Protection and to the unremitting work of its chairman Mr. Harold J. Coolidge. Until September, 1958, Mr. Coolidge was also chairman of the Survival Service; he has now become chairman of the Union's new International Committee on National Parks.

\section{Vanishing Birds}

The 1949 conference at Lake Success prepared the following list of examples of endangered species: Arabian ostrich ; 
Hawaiian goose or ne-ne; New Caledonian kagou; Indian pink-headed duck ; Australian ground parakeet ; Laysan duck ; Marianas mallard; Cuban ivory-billed woodpecker; Bermuda petrel ; Marianas megapode; California condor; Eskimo curlew; North American whooping crane. This list, as readers of J. C. Greenway's "Extinct and Vanishing Birds of the World ", reviewed on page 36 , will realize does no more than draw attention to a few of the many birds for which vigorous action is necessary. The Survival Service entrusts all such action to the International Council for Bird Preservation and, in 1958, the president of that council, Dr. Dillon Ripley, reported upon five of these thirteen birds and also upon another very important bird-Steller's albatross which, until late in the nineteenth century inhabited Torishima Island and other places round Japan in numbers estimated at more than a million. Between 1887 and 1903 feather hunters slaughtered more than half a million of these birds on Torishima and further persecution followed. By 1933 this albatross had almost vanished, but in 1957 twenty-three were discovered on Torishima and in 1957 the island was made a special reserve. In January, 1958, there were twenty-eight adults ; eggs were being incubated and seven chicks had hatched.

Hawaiian Goose.-As most readers will know, the Hawaiian goose, or ne-ne, which was threatened with extermination in Hawaii, has been very successfully bred at the Wildfowl Trust, Slimbridge, England. Specimens have been distributed to other centres in England, France, Holland, Switzerland and U.S.A. The main object in rearing these birds is eventually to strengthen the wild stock. In 1956-5\%, Dr. William H. Elder made a survey of the wild birds and saw a number of ne-ne with their young. Their nesting places have been made protected areas.

The Pan-American Section of the I.C.B.P. has just published a report on the ne-ne (see note).

Indian Pink-headed Duck.-The Indian National Section of the I.C.B.P. has suggested a field investigation to discover whether this duck still exists. An application for $£ 750$ to carry out this project has been made to I.U.C.N. for submission to UNESCO.

Laysan Duck.-Efforts will be made to imtroduce the Laysan Island duck into Lisianski Island also-both are in the Hawaiian group. The breeding of a captive stock is also being attempted. Ivory-billed Woodpecker.-The continental form of the ivorybilled woodpecker is extinct. In 1956, in an effort to save the Cuban sub-species, the Pan-American Section, I.C.B.P., sent 
Mr. and Mrs. George Lamb to Cuba. In his report (see note) Mr. Lamb states that the bird, once widely distributed, is limited to a remote area in Northern Oriente Province and numbers have become dangerously low. Land clearing and lumbering activities have extirpated the bird from most of its former range, because its habitat is composed of pine forests growing on deep lateritic soil, with strands and islands of hard wood. In $1956 \mathrm{Mr}$. Lamb found only six pairs (twelve individuals) and a "very probable" young bird. Immediate measures for conservation of this species are necessary, and it is fortunate that the major land owners have agreed to co-operate. Nesting and roosting places in pine trees are the chief need, and a refuge in the Bandolero region, which is particularly suitable, has been suggested. Measures proposed are the employment of wardens, illustrated posters forbidding disturbance of bird and nest, and nesting boxes.

Whooping Crane.-It seems that 1958 was a good breeding season for the whooping crane in northern Canada. On 24th October there were eleven adults and five young at the winter refuge in Texas and the fifteen more known wild adults were presumably on their way south, perhaps some of them with young.

Further information about the ne-ne, the Laysan duck, the ivory-billed woodpecker, the Eskimo curlew, the whooping crane and other American birds and mammals is given in Oryx IV, 6, pp. 365-372.

\section{Constitution of the Survival Service Commission}

Like other permanent commissions of the I.U.C.N., the Survival Service is established under rules made by the Union's Executive Board. The chairman is elected by the General Assembly for a period of two years. The vice-chairman and other members are nominated by the Executive Board after consultation with the Commission, normally for four years. All members of the Commission are eligible for re-appointment after serving their term. A report on the Commission's work is submitted at each General Assembly of the Union.

The members of the Commission appointed at the VIth General Assembly of the I.U.C.N. at Athens in September, 1958, or since nominated, are :-

Chairman : Lieut.-Colonel C. L. Boyle, Secretary, The Fauna Preservation Society.

Vice-Chairman : Dr. Jean Dorst, Museum National d'Histoire Naturelle, Paris. 
Members: Dr. R. Bigalke, Director, National Zoological Gardens of South Africa; Mr. H. J. Coolidge, Executive Director, Pacific Science Board, U.S.A.; Mr. Mervyn Cowie, Director, Royal National Parks of Kenya; Mr. E. P. Gee, Indian Board for Wild Life; Mr. James C. Greenway, jnr., Harvard University, Massachusetts, U.S.A. (representing the International Council for Bird Preservation); M. Luc Hoffman, Station de la Tour du Valat, Le Sambuc, France; M. J-J, Petter, Laboratoire d'Ecologie et de Protection de la Nature, Brunnoy, France; M. Jacques Verschuren, Parc National Albert, Congo Belge.

Note.-The following reports have been published by the Pan-American Section of the International Council for Bird Preservation and may be obtained from the Treasurer, Mr. Charles B. Belt, 233 Broadway, New York 7, New York, U.S.A.

Research Report No. 1.

"The Ivory-billed Woodpecker in Cuba" by George R. Lamb. 2 dollars.

Research Report No. 2.

" On the Endangered Species of Birds in the U.S. Virgin Islands" by George R. Lamb. 50 cents.

Research Report No. 3.

"A Research Report on the Hawaiian Goose or Ne-ne" by Willam H. Elder. 25 cents. 